DOI: $\square$ https://doi.org/10.15407/techned2020.04.046

\title{
THE PROBLEM OF ELECTRIC POWER STORAGES' PLACEMENT IN THE IPS OF UKRAINE TAKING INTO ACCOUNT ITS INFLUENCE ON THE POWER FLOWS TRANSMITTED BY CONTROLLED CUTSETS
}

Journal

Publisher

ISSN

Issue

Pages
Tekhnichna elektrodynamika

Institute of Electrodynamics National Academy of Science of Ukraine 1607-7970 (print), 2218-1903 (online)

No 4, 2020 (July/August)

$46-50$

\section{Authors}

\section{O.F. Butkevych ${ }^{1,2 *}$, N.T. Yunieieva ${ }^{1}$, T.M. Hurieieva ${ }^{1}$, P.I. Stetsyuk ${ }^{3 * *}$}

1 - Institute of Electrodynamics National Academy of Science of Ukraine,

Peremohy ave., 56, Kyiv, 03057, Ukraine,

e-mail: butkevych@ied.org.ua

2- National Technical University of Ukraine "Igor Sikorsky Kyiv Polytechnic Institute", pr. Peremohy, 37, Kyiv, 03056, Ukraine

3. Glushkov Institute of Cybernetics of the National Academy of Sciences of Ukraine, Glushkov avenue, 40, Kyiv, 03187

* ORCID ID : https://orcid.org/0000-0002-6613-0911

** ORCID ID : https://orcid.org/0000-0003-4036-2543

\section{Abstract}

It is shown that when creating of electric energy storage system (EESS) in the Interconnected Power System (IPS) of Ukraine it is advisable to take into account the influence of the distribution (considering both location and power) of EESS batteries on the flows of active power transmitted by "problematic" controlled cutsets of the IPS of Ukraine. The method for solving the EESS distribution's problem taking into account the specified influence is proposed. References 3, table 1.

Key words: interconnected power system, renewable energy sources, electric energy storages' placement. 
Received: 28.02.2020

Accepted: 12.05 .2020

Published: 26.06.2020

\section{References}

1. 2018 Non-Financial Report "10 steps towards Europe". State enterprise National power company Ukrenergo. URL: https://ua.energy/wp-content/uploads/2019/07/UE_NFR_2018_Eng . $\mathrm{pdf}$ (accessed: 04.03.2020)

2. Energy storage Ukraine 2020: first projects, steps, and challenges. Discussion Platform 12 December 2019. URL:

https://mim.kiev.ua/events/view/energy-storage-ukraine-2020-persh-proekti-kroki-ta-vikliki (accessed: 09.01.2020).

3. Gamm A.Z., Golub I.I. Sensors and weaknesses in power systems. Irkutsk: Melentiev Energy Systems Institute of the Siberian Branch of the RAS, 1996. 96 p. (Rus.)

$\underline{\text { PDF }}$

This work is licensed under a Creative Commons Attribution-NonCommercial-NoDerivatives $\underline{4.0 \text { International License }}$ 
